\title{
Tourist Preference and Destination Competitiveness Using the AHP - TOPSIS Hybrid Model
}

\author{
(A Case Study in Kupang City, Nusa Tenggara Timur Province)
}

\author{
Rio Benedicto Bire*, Agustino L. F. Conterius, Asbi Nasar \\ Tourism Department \\ Kupang State Polytechnic \\ Kupang, Indonesia \\ *rio.bire@gmail.com
}

\begin{abstract}
This research aims to draw a blueprint of factors influencing tourist's choice of destination, and to identify tourism destination competitiveness in Kupang City of the Nusa Tenggara Timur (NTT) Province. Scarcity of empirical studies related to the topic and significant potential for tourism development in the context of NTT justifies a gap for the aforementioned agenda. In fulfilling the aim of study, we employed a quantitative method through an application of a hybrid multi criteria decision making (MCDM) method by combining the Analytical Hierarchy Process (AHP) and Technique for Order Preference by Similarity to Ideal Solution (TOPSIS). Data were obtained by questionnaire spread upon visiting tourists. Results point that safety was the dominant factor influencing the destination choice of tourists, while self-esteem was found to be the least important factor. Importance of factor indicators showed that society friendliness, need for eating and drinking, a crime-free environment, and spending time with relatives or family were the 4 most important criteria. Further results regarding destination competitiveness identified Warna Oesapa Beach to be the most favorite destination, while Gua Monyet Tenau was the least favorable place. Findings of this research is contended to be beneficial in the context of understanding how do tourists perceive and prefer choosing tourism destinations offered in Kupang City. Accordingly, tourism stakeholders from the supply side are equipped with essential inputs for planning destination attributes worth developing and promoting, and specifically in regards to destination brand repositioning.
\end{abstract}

Keywords-tourist preference, destination competitiveness, AHP, TOPSIS

\section{INTRODUCTION}

Tourism is one of the world's largest and fastest growing industries [1] which can provide the means to overcome macroeconomic issues such as unemployment, inflation, and stagnant growth [2]. Considering the global development and a promising future, many countries have considered tourism to be a priority sector within their national economic plans, and aside from the national scale, tourism is also instrumental for regional development [3,4]. As a driver of local economy, tourism development is a necessary enabler.

Tourism development is enabled and manifested through destination competitiveness, and initiatives for enhancing competitiveness of regional tourism can stem from drawing up a blueprint [5] that takes into account tourist preference and destination competitiveness. An empirical study on destination competitiveness is envisioned to provide a blueprint on understanding why do tourists visit tourist destinations, and moreover to provide insights on what factors influence their decision. Furthermore, the thematic study allows for identifying the relative rankings of destinations which is essential for marketing positioning purposes. Insights from such research are viewed as beneficial for tourism stakeholders particularly from the supply side for reviewing and planning future development initiatives.

Multi Criteria Decision Making (MCDM) is a multiple criteria analytical method used to evaluate a set of alternatives [6] which can assist for examining tourist preference and destination competitiveness. A prominent MCDM technique is the Analytical Hierarchy Process (AHP), which provides decision-makers with a problem-solving framework by weighing criteria from pair-wise comparisons. AHP is particularly convenient for cases where essential data is subjective, and is widely used in researches concerned with tourism planning. Another popular MCDM model is the Technique for Order Preference by Similarity to Ideal Solution (TOPSIS), which provides decision-makers with additional means for choosing between alternatives. The underlying principle of TOPSIS is that the preferred solution of alternatives should have the shortest distance towards the ideal positive solution and the furthest distance from the ideal negative solution. Accordingly, the preferred solution is comprised of all the best indices. TOPSIS is preferable as it is mathematically simple yet is largely flexible in the choice set.

This research aims to demonstrate the application of the hybrid multi criteria decision making (MCDM) combining the Analytic Hierarchy Process (AHP) and Technique for Order of 
Preference by Similarity to Ideal Solution (TOPSIS) to evaluate destination competitiveness based on tourist preferences in Kupang City of the Nusa Tenggara Timur (NTT) Province. NTT in recent years has attracted increasing attention regarding its tourism potential, where labels such as "the new tourism territory" and "the new Bali" have been attached to NTT by government stakeholders, underlining a promising future for tourism development. Tourist visits to NTT in 2018 recorded a figure of 1.2 million people which increased fourfold from year 2014 [7]. Kupang City as the capital of NTT Province is contended to serve as a satisfactory starting point for the aforementioned thematic study. There are 5 tourism destinations in Kupang City that recorded the highest numbers of visitors in 2019, which are Lasiana Beach, Nostalgia Park, Gua Monyet Tenau, Oesapa Warna Beach, and Nunsui Beach. These destinations are regarded to serve as sufficient alternatives for the analysis of destination competitiveness based on tourist preference.

Despite possessing development potential and significance in NTT, empirical studies regarding tourist preferences in relation to destination competitiveness are severely lacking in proportion. This research is considered to potentially provide essential groundwork for future tourist preference and destination competitiveness studies for supporting tourism development initiatives. These particular points justify the gap for this study.

\section{LITERATURE REVIEW}

Tourist choice of destination is a complex, multidimensional process that involves several stages of decision making [8], and throughout this process, a tourist commonly would confide to a set of criteria. Moreover, the choice of destination is influenced by various factors which generally can be categorized into that of internal or psychological factors, and external or non-psychological factors. The process of which a tourist makes the complex decision that encapsulates the choice of destination has become a popular empirical study among researches. A particular factor strongly related to the choice of a destination is motivation [5]. Motivation has been considered as one of the most important factors in explaining tourist behavior [9] which is categorized into the psychological spectrum of an individual. Studies relating tourist motivation and the choice of destination are considered to play an important role in predicting future travelling patterns. Accordingly, such analysis will contribute as critical inputs regarding destination planning and marketing by the supply side of stakeholders. Travel motivation is considered a complex field of research [10] that encompasses a handful of theories and typologies. One of the most traditional yet still relevant motivational theories used in various fields of studies is Maslow's motivation hierarchy of needs. The motivation hierarchy of needs that distributes human motivation into 5 hierarchical levels, namely psychological, safety, social, selfesteem, and self-actualization needs has been adapted into the field of tourism by Pearce [11].
In the tourism setting, the physiological factor is related to the intrinsic benefits offered by a destination [12], thus categorized as a pull factor. It is considered to be related to that of the human senses such as visualization of green grass or yellow sand. The safety motivation deals with symbolic perceptions [13] which can be offered by a destination through accommodation services, accessibility, and price [14]. The social motivation is symbolic in nature which deals with the expression of a tourist in relation to one another such as relatives or family members. Moreover, the self-esteem factor is related to the human psychology and emotion [12]. A tourist may fulfill such needs by being in a "happening" place [14] where visiting the destination is a popular topic of discussion in the lifestyle of the tourist's social surroundings [15]. In this sense, prestige is attached to the destination. In the selfactualization spectrum, the need is associated with selfsufficiency and the destination identity which is the reflection of the tourist itself [13]. This study adapts the 5 criteria of hierarchy of motivation in tourism from Balakrishnan et al., [12] and Pearce [11]. Moreover, we break-down the 5 factors into indicators as displayed in Figure 1.

If motivation is one's process of initiating, directing, and retaining behavior, preference is referred to the stage that stands in between the need and the behavior itself [16]. Individual behavior is triggered by motivation [17], whilst the acceptance or rejection of a product alternative is more influenced by the individual preference. Accordingly, it can be concluded that the process of choosing a destination is determined by tourist preference which is influenced by motivation. Preference analysis in this research encompasses tourist preference regarding factors or criteria for choosing a tourist destination, and the preference of tourism destination alternatives. Accordingly, this research links motivational factors with preference rankings in order to explain the principle preference criteria for tourism destinations. The hierarchical scheme of tourism destination preference in this research is displayed in Figure 1.

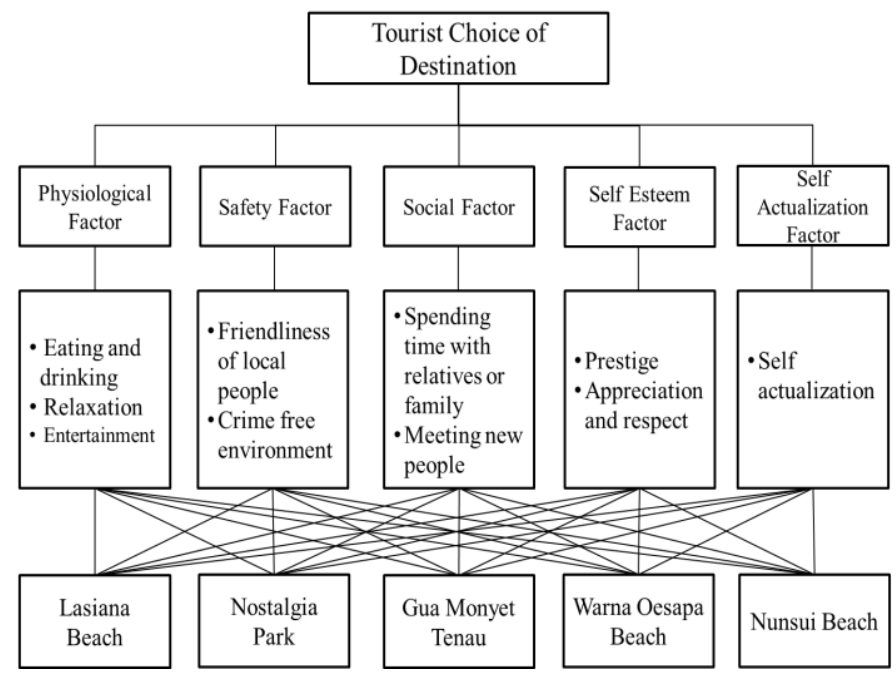

Fig. 1. Hierarchy of destination selection. 


\section{RESEARCH METHODS}

This research leans toward a quantitative approach. A preliminary study of identifying and selecting destination alternatives was conducted based on the criteria of the highest recorded amount of tourist visits to tourism destinations in Kupang City of NTT in year 2019 and through direct observation. Based on these criteria, 5 top destinations were selected. Subsequently, the evaluation hierarchy was designed through synthesis of literature related to motivational factors and tourist preferences. Data collection was administered through questionnaire spread upon visiting tourists in each selected destination in the study. Tourists were sampled based on the convenience sampling technique, and a total of 350 questionnaires were distributed and collected. Following the data collection was data analysis which underwent two main stages, namely the calculation of motivational criteria weights through the Analytical Hierarchy Process (AHP) method, and the rankings of destination alternatives through the Technique for Order of Preference by Similarity to Ideal Solution (TOPSIS) method. These two methods are briefly explained in the following:

\section{A. Analytical Hierarchy Process (AHP)}

AHP facilitates for the weighting of criteria i.e. the hierarchy of motivational factors through pairwise comparisons of each criterion. The sequences for AHP are as follows:

- Define the overall goal

- Construct the hierarchical structure

- Construct pairwise comparison matrix

- Perform judgment for pairwise comparisons

- Synthesize pairwise comparisons

- Check for consistency

\section{B. Technique for Order of Preference by Similarity to Ideal Solution (TOPSIS)}

TOPSIS is employed in this research to conduct the rankings of destination alternatives. The basic principal of the TOPSIS method is that the best alternative should have the closest Euclidean distance towards the positive ideal solution, and the furthest Euclidean distance towards the negative ideal solution. The sequences for conducting TOPSIS are as follows:

- Establish a performance matrix

- Normalize the decision matrix

- Calculate weighted normalized decision matrix

- Determine the positive ideal and negative ideal solutions

- Calculate relative closeness to the ideal solution

- Rank the alternatives

\section{RESULTS AND DISCUSSION}

Table 1 shows the relative weights of each criterion on the AHP hierarchy. Results point safety to be the dominant factor for tourists in choosing a destination. The safety need is categorized as that of symbolic [13] which is expressed through tolerance upon a state of deficiency. Similar findings are recognized in Hsu et al. [5] where although not concluded as the most important factor, safety was realized as a significant regard by tourists. Considering the state of tourism in this recent time of "the new normal" as a consequence of the covid-19 outbreak and pandemic, the safety factor is indeed of inevitable significance for reviving tourism in terms of attracting visitors from the supply viewpoint. This particular finding suggests that destinations in Kupang City are able to fulfill the need of safety for its visitors. With a weight of 0.3 , the physiological factor ranks 2 nd in the priority scale. This very basic need of humans is categorized as that of intrinsic benefits offered by a destination as suggested in Balakrishnan et al., [12], and manifested in the tangible form such as food and beverages, and intangible forms such as relaxation. The importance of the physiological need is also showed in Hsu et al. [5]. On the other hand, self-esteem factor is recognized as the least important factor in the priority scale. Self-esteem itself leans towards the psychological field related to human emotions, thus is symbolic in nature [18]. The low rating of this factor suggests that the destinations in Kupang City do not necessarily realize the image of a "happening place" for its visitors which should in fact create a feeling of social pride. This may also indicate low prestige attached to the destinations.

TABLE I. WEIGHTS OF FACTORS AND INDICATORS

\begin{tabular}{|l|l|l|l|l|}
\hline \multicolumn{1}{|c|}{ Factor } & Weight & \multicolumn{1}{|c|}{ Indicator } & \multicolumn{1}{c|}{$\begin{array}{c}\text { Local } \\
\text { Weight }\end{array}$} & $\begin{array}{c}\text { Global } \\
\text { Weight }\end{array}$ \\
\hline Physiological & 0.3 & $\begin{array}{l}\text { Eating and } \\
\text { drinking }\end{array}$ & 0.507 & 0.152 \\
\hline & & Relaxation & 0.224 & 0.067 \\
\hline Safety & 0.358 & $\begin{array}{l}\text { Entertainment } \\
\text { local people }\end{array}$ & 0.268 & 0.080 \\
\hline Social & 0.17 & $\begin{array}{l}\text { Crime-free } \\
\text { environment }\end{array}$ & 0.594 & 0.212 \\
\hline $\begin{array}{l}\text { Spending time } \\
\text { relatives/family } \\
\text { members }\end{array}$ & 0.803 & 0.136 \\
\hline Self-esteem & 0.052 & $\begin{array}{l}\text { Meeting new } \\
\text { people }\end{array}$ & 0.196 & 0.033 \\
\hline $\begin{array}{l}\text { Self- } \\
\text { actualization }\end{array}$ & 0.117 & $\begin{array}{l}\text { Appreciation and } \\
\text { respect }\end{array}$ & 0.298 & 0.015 \\
\hline
\end{tabular}

Results from the weightings of the indicators of factors in Table 1 show that the two indicators of safety dominate the top ranks. Friendliness of local people is the first priority with a global weight of 0.212 , followed by need for eating and drinking (0.152), crime-free environment $(0.145)$, and the need 
for spending time with relatives or family (0.136). These particular points underline that apart from offering an environment of minimum crime risk with friendly locals, destinations in Kupang City do propose for the fulfillment of quality and variety of food and beverages. The relatively high priority for spending time with relatives and family compared to meeting new people (8th in rank) suggest that the majority of visitors are locals and not those of foreign tourists. This finding is similar to that of Hsu et al. [5]. Compared to other popular tourist destinations in the NTT Province, Kupang City does record fewer foreign tourist visits, and social interactions in the destinations are more likely of those with known relatives. The importance of need for spending time with relatives and friends over new people is also shown in research by Mohamad and Jamil [19] and Hsu et al. [5]. On the contrary, the need for appreciation and respect lies in the bottom rank of priority with a weight of 0.015 . In specific, this finding suggests the need for revitalizing the branding of destinations in Kupang City which could accentuate a symbolic feature thus creating an exclusivity aura.

Results from the destination competitiveness analysis are shown in Table 2 and Table 3. It points Warna Oesapa Beach to be the most competitive destination ahead of Nostalgia Park, Lasiana beach, Nunsui Beach, and Gua Monyet Tenau. As displayed in Table 2, Warna Oesapa Beach is the most popular destination based on all criteria excluding crime-free environment, spending time with relatives or family, and selfactualization. The emergence of Warna Oesapa Beach as the top destination is not surprising considering its appeal of natural landscape and for the variety of food and beverages offered relative to its competitors. These elements indeed provide an essential supply for supporting the fulfillment of the psychological needs of tourists including that of relaxation and entertainment, which is parallel to Balakrishnan et al. [12]. The importance of beautiful scenery is also emphasized in Nicolan and Mas [20]. In addition, such supply is viewed to be an essential element for enhancing the fulfillment of prestige, as well as being appreciated and respected. This is appropriate considering that photographs of destinations' natural landscape and local food is a popular trend amongst millennials in terms of social media uploads as noted in Liu et al., [21] and Arviani et al., [22], such as that in Instagram, Facebook, Twitter and WhatsApp in order to be acknowledged by their peers. The relatively high figures in meeting new people $(0.0167)$ for Warna Oesapa Beach is considered appropriate as the majority of visitors are that of the younger generation who are in their prime for socializing and meeting new people. The priority for meeting new people amongst millennials who are not yet married are also shown in Rita et al., [23].
Lasiana Beach which ranks as the $3^{\text {rd }}$ favorite destination is superior relative to its competitors based on spending time with relatives or family (0.0669) and self-actualization (0.544) criteria. These two indicators are contended to stand out due to the longevity of Lasiana Beach as the prime tourism attraction in offering a suitable environment for family recreation and recreational social gatherings before the emergence and development of other destinations in Kupang City. Moreover, Lasiana Beach does present a spacious setting which renders the place suitable for fulfilling self-actualization needs. Nostalgia Park which is the $2^{\text {nd }}$ in the favorite destinations table shows superiority in regards to the safety factor of crime risk free environment. Due to being located in a relatively crowded urban area, Nostalgia Park is presumed to present a minimum crime risk for its visitors in comparison to its competitors. The presence of a non-permanent police post within the area of Nostalgia Park is perceived to enhance the attribute weight. Additionally, it is also noticed through direct observation that the presence of visitors since the early morning for exercising does validate the fulfilling of the attribute. The low popularity of Gua Monyet Tenau which lies at the bottom of ranks in Table 2 reflects its lowest rankings for all criteria of competitiveness as displayed in Table 2. Apart from the attraction for monkey sightseeing, there would be almost an absence of supply for fulfilling visitor needs. Within its location, there is only one kiosk offering a limited variety of food and beverage supply. This particular finding should properly prompt the management and local government upon striving for the revitalization of Gua Monyet Tenau in order to not be left behind in competitiveness amongst other new sites which in recent times has been constantly developed in Kupang City.

It should be noted that the true choice set of tourists is perhaps generally unknown to the researchers [24] as there may occur biases within the process of decision-making. Moreover, Sirakaya and Woodside [25] note that there would be no model that would fit all decision-makers and every decision situation. This research did not include a richer set of motivational criteria such as that of price, which is found in Nicolan and Mas [20] and Suryaningsih et al., [26], or a breakdown of the entertainment criteria which may entail a variety of dimensions such as found in Enright and Newton [27]. Further studies may include a more comprehensive set of factors in order to validate the reliability of our findings. Furthermore, the study on destination competitiveness in the NTT Province can include or focus on covering a wider geographical sample, particularly the "7 tourism destination estates" which recently has been promoted by NTT's government. Such empirical study can provide significant insights for the development of tourism in NTT. 
TABLE II. OVERALL PERFormance MEASURES OF DESTINATIONS

\begin{tabular}{|l|l|l|l|l|l|}
\hline \multicolumn{1}{|c|}{ Indicator } & Lasiana & $\begin{array}{c}\text { Nostalgia } \\
\text { Park }\end{array}$ & $\begin{array}{c}\text { Gua } \\
\text { Monyet }\end{array}$ & $\begin{array}{c}\text { Warna } \\
\text { Oesapa }\end{array}$ & Nunsui \\
\hline Eating and drinking & 0.070 & 0.078 & 0.042 & 0.085 & 0.053 \\
\hline Relaxation & 0.032 & 0.029 & 0.022 & 0.033 & 0.030 \\
\hline Entertainment & 0.035 & 0.036 & 0.032 & 0.042 & 0.033 \\
\hline Friendliness of local people & 0.099 & 0.095 & 0.083 & 0.104 & 0.091 \\
\hline Crime-free environment & 0.073 & 0.067 & 0.052 & 0.066 & 0.062 \\
\hline Time with relatives/family & 0.066 & 0.060 & 0.048 & 0.066 & 0.061 \\
\hline Meeting new people & 0.015 & 0.016 & 0.012 & 0.016 & 0.014 \\
\hline Prestige & 0.017 & 0.016 & 0.014 & 0.017 & 0.015 \\
\hline Appreciation and respect & 0.006 & 0.006 & 0.006 & 0.007 & 0.007 \\
\hline Self-actualization & 0.054 & 0.053 & 0.046 & 0.054 & 0.052 \\
\hline
\end{tabular}

TABLE III. FINAL RANK OF DESTINATIONS

\begin{tabular}{|l|c|c|}
\hline \multicolumn{1}{|c|}{ Destination } & Rank & $\begin{array}{c}\text { Similarity to Ideal } \\
\text { Solution }\end{array}$ \\
\hline Lasiana Beach & 3 & 0.722 \\
\hline Nostalgia Park & 2 & 0.723 \\
\hline Gua Monyet Tenau & 5 & 0.000 \\
\hline Warna Beach Oesapa & 1 & 0.890 \\
\hline Nunsui Beach & 4 & 0.387 \\
\hline
\end{tabular}

\section{CONCLUSION}

This research investigated tourist preferences in choosing a destination based on an adaptation of Maslow's hierarchy of needs in tourism which was readjusted from Balakrishnan [12] and Pearce [11]. This study further analyzed destination competitiveness based on the blueprint of weights obtained from the aforementioned preferences. We demonstrated the efficacy of a hybrid MCDM method combining AHP and TOPSIS in fulfilling the research agenda upon the 5 most popular destinations in Kupang City.

Research results show that safety need is the most important consideration for tourists in choosing a destination to visit. On the contrary, self-esteem need is the least prioritized criteria. In regards to factor indicators, the four top priorities are friendliness of local people, eating and drinking needs, crime risk free environment, and spending time with relatives and family. On the other hand, need for appreciation and respect was the least considered indicator. In terms of destination competitiveness, Warna Oesapa Beach is the most favorable place, followed by Nostalgia Park, Lasiana Beach, Nunsui Beach, and Gua Monyet Tenau.

Findings of this study are contended to be beneficial in regards to understanding how do tourists consider on choosing a destination to visit, and moreover generating a blueprint on how they view destinations in Kupang City. The supply side of stakeholders is hence provided with relevant information upon attributes of the destinations worth developing and promoting. This research is without limitations, where apart from the limited number of destinations analyzed, the timeframe of study is another hindrance to a more comprehensive result. Further researches can verify the validity and reliability of our findings through a more comprehensive set of motivational criteria, a longer time span of study, and including a richer set of destinations for analysis.

\section{REFERENCES}

[1] M.M. Ulkhaq, P.Y. Akshinta, R.L. artadhi, and W.S. Nugroho, "Assessing sustainable rural community tourism using the AHP and TOPSIS approaches under fuzzy environment," InMATEC Web of Conferences, vol. 68, p. 09003, 2016.

[2] H.C. Choi and E. Sirakaya, "Sustainability indicators for managing community tourism," Tourism management, vol. 27 , no. 6, pp. 1274-89, 2006.

[3] S. Chaabouni, "China's regional tourism efficiency: A two-stage double bootstrap data envelopment analysis," Journal of destination marketing \& management, vo. 11, pp. 183-91, 2019.

[4] S. Soebagyo, "Strategi pengembangan pariwisata di Indonesia," Liquidity, vol. 1, no. 2, pp. 153-8, 2012.

[5] T.K. Hsu, Y.F. Tsai, and H.H. Wu, "The preference analysis for touris choice of destination: A case study of Taiwan," Tourism management, vol. 30, no. 2, pp. 288-297, 2009.

[6] T.C. Wang and H.D. Lee, "Developing a fuzzy TOPSIS approach based on subjective weights and objective weights," Expert systems with applications, vol. 36, no. 5, pp. 8980-5, 2009

[7] BPS Nusa Tenggara Timur, Nusa Tenggara Timur Province in Figures 2019.

[8] L. Wu, J. Zhang, and A. Fujiwara, "Representing tourists' heterogeneous choices of destination and travel party with an integrated latent class and nested logit model," Tourism Management, vol. 32, no. 6, pp. 1407-13, 2009.

[9] M. Li and L.A. Cai, "The effects of personal values on travel motivation and behavioral intention," Journal of Travel Research, vol. 51, no. 4, pp. 473-87, 2012

[10] T.H. Do and W. Shih, "Destination decision-making process based on a hybrid MCDM model combining DEMATEL and ANP: The Case of Vietnam as a Destination," Modern Economy, vol. 7, no. 09, p. 966, 2016

[11] P.L. Pearce, "Fundamentals of tourist motivation," Tourism research: Critiques and challenges, pp. 113-34, 1993.

[12] M.S. Balakrishnan, R. Nekhili, and C. Lewis, "Destination brand components," International Journal of Culture, Tourism and Hospitality Research, 2011.

[13] E.E. Ibrahim and J.A. Gill, "positioning strategy for a tourist destination, based on analysis of customers' perceptions and satisfactions,' Marketing intelligence \& planning, 2005.

[14] G. Hankinson, "Destination brand images: a business tourism perspective," Journal of Services Marketing, 2005.

[15] M.J. Gross, C. Brien, and G. Brown, "Examining the dimensions of a lifestyle tourism destination," International Journal of Culture, Tourism and Hospitality Research, 2008 
[16] X. Tran and L. Ralston, "Tourist preferences influence of unconscious needs," Annals of Tourism Research, vol. 33, no. 2, pp. 424-41, 2006

[17] G. Ashworth and B. Goodall, "Marketing tourism places," vol. 2, 2006.

[18] S. Baloglu and K.W. McCleary, "international pleasure travelers' images of four Mediterranean destinations: A comparison of visitors and nonvisitors," Journal of travel research, vol. 38, no. 2, pp. 144-52, 1999.

[19] D. Mohamad and R.M. Jamil, "A preference analysis model for selecting tourist destinations based on motivational factors: A case study in Kedah, Malaysia," Procedia-Social and Behavioral Sciences, vol. 65, pp. 20-5, 2012.

[20] J.L. Nicolau and F.J. Mas, "The influence of distance and prices on the choice of tourist destinations: The moderating role of motivations,' Tourism Management, vol. 27, no. 5, pp. 982-96, 2006.

[21] H. Liu, L. Wu, ans X. Li, "Social media envy: How experience sharing on social networking sites drives millennials' aspirational tourism consumption," Journal of Travel Research, vol. 58, no. 3, pp. 355-69, 2019.
[22] H. Arviani, G.S. Prasetyo, and V.V. Walgunadi, "Instagram and Millennial Generation:\# Explorebanyuwangi Analysis," In 2nd International Media Conference 2019, pp. 180-192, 2020.

[23] P. Rita, A. Brochado, and L. Dimova, "Millennials' travel motivations and desired activities within destinations: A comparative study of the US and the UK," Current Issues in Tourism, vol. 22, no. 16, pp. 2034-50, 2019.

[24] J. Swait, "Choice set generation within the generalized extreme value family of discrete choice models," Transportation Research Part B: Methodological, vol. 35, no. 7, pp. 643-66, 2001.

[25] E. Sirakaya and A.G. Woodside, "Building and testing theories of decision making by travellers," Tourism management, vol. 26, no. 6, pp. 815-32, 2005

[26] I.B. Suryaningsih, K.S. Nugraha, and D.K. Moelyadi, "Travel Choice Component: Is The Price Important For Open Trip Tourists?" Jurnal Manajemen, vol. 24, no. 2, pp. 266-81, 2020.

[27] M.J. Enright and J. Newton, "Tourism destination competitiveness: a quantitative approach," Tourism management, vol. 25 , no. 6 , pp. $777-88$, 2004 